\title{
Hungarian ethnic minority higher education students in different countries of Central Europe
}

\author{
Pusztai, Gabriella ${ }^{\text {; }}$ Márkus, Zsuzsanna ${ }^{a}$
}

${ }^{\mathrm{a} C e n t e r}$ for Higher Education Research and Development, University of Debrecen, Hungary

\begin{abstract}
There are about 3 million Hungarians living as a minority outside Hungary in 7 countries of Central Europe. In some of those countries they still live in a nearly homogeneous block, whereas in others they live in diaspora. Their access to education in their mother tongue also differs. Our research covered the Hungarian institutions of higher education in the four countries with largest Hungarian minority groups, and we undertook a comparative study of their students. For our investigation we compared the families' social status. We used data on 1739 students from 13 institutions. We concluded that indigenous Hungarian minority students did not produce homogeneous results in the categories that were examined, which led us to the discovery of important differences.
\end{abstract}

Keywords: Hungarian minority; higher education; family background, comparative study. 


\section{Introduction}

Hungarians have been incorporated into the $7 \mathrm{CEE}$ countries involuntarily after World War I, which left large Hungarian communities under the control of countries they had not been attached to by any form of linguistic, cultural or national identity (Kozma, 2003; Pasztor, 2006). The new majorities, although to a varying extent in different eras, questioned their right for a mother tongue schooling. As a result, the controversial relationship between national identity and citizenship still has its negative effects. Communism proclaimed the disappearance of nations, and "communist ethnic diversity mismanagement" (Cordell et al., 2013: 236), i.e. the suppression of human rights of ethnic and linguistic minorities by communist totalitarianism, led to the collective institutional discrimination and glass ceilings in education of ethnic minorities, similary to other castelike minority groups (Ogbu, 1982; Kanu, 2007).

During the communist era there were political obstacles to mother tongue education; therefore it became one of the central political issues addressed by the representatives of Hungarian minority groups after the democratic transition (Agarin et al., 2016; Lambrev, 2016). On the one hand, minority schools are means of protecting a minority and maintaining their identity; on the other hand, access to mother tongue education is crucial to a successful school career. Their goals are in accordance with the UNESCO statement: indigenous groups in the world "often face discrimination in school that is reinforced by the fact that the language used in the classroom may not be one that they speak" at home. In order to avoid collective institutional discrimination, it is essential that all learning materials, tools and students' assessment are provided in a language they are familiar with (Despagne, 2013). In spite of the European integration there is a "de facto inequality between individual members of society belonging to communities different from the majority population" (Cordell et al., 2013: 237).

\section{Ethnic Hungarian Students}

Ethnic Hungarian communities in the different countries show different features in terms of their proportion in the population, social status, geographical distribution, settlement structure and language use. From the perspective of education politics, the countries with ethnic Hungarian communities can be classified into two groups. One of the main differences accounting for the other variances is that most ethnic Hungarians in Ukraine, Rumania, Slovakia and Serbia live in areas where Hungarians are in majority, while most Hungarian communities in Austria, Slovenia and Croatia do not (Csete et al., 2010). Our study focuses on four relatively large ethnic Hungarian groups. Our data are from the regions populated by Hungarians, 
Indigenous Hungarians are behind the ethnic majority in all regions in terms of participation in, and level of, education. There is a tendency for the disadvantage to grow as higher education is approached (Veres, 2013; Gábrity \& Takács, 2015; Orosz, 2015; Bacskai et al., 2015). It is an appalling fact considering that before 1920 Hungarians' education statistics in Austria-Hungary were much better than those of Slovakians, Romanians, Ukrainians and Serbians (Hanák, 1983). After that, the mother tongue education of minority Hungarians was continuously declining because of the nation states' educational policies, which failed to support minorities' equal opportunities and were interested in the abolishment of ethnic communities (Csata, 2004; Agarin et al., 2016). During the last 25 years there has been a slight expansion in the structure and capacity of education . In spite of this short revival, minorities' level of education is still behind that of the majority, and there is a statistically significant fall in the Hungarian population. Social mobility mainly means one step upward; it is due to structural changes, and the majority population's statistics are much better in this respect as well (Papp Z., 2011). Recent data clearly show that in each country ethnic Hungarians with higher education degrees are underrepresented in comparison to the majority population and to Hungarians' proportion in the population (Csernyicskó \& Ferenc, 2014). Hungarian communities, which have been living as a minority for a century, only have access to a very limited range of public and higher education in their mother tongue. The system of vocational training has not been developed yet; there is no medical and legal, and only sporadic technical and economic training in higher education. Owing to the lack of variety in Hungarian degree programmes, several Hungarian-speaking families opt for state language education from the beginning in hope of more promising life and career prospects. Their other option is emigration, which deprives the Hungarian minority of its highly qualified members (Papp Z., 2011).

We can keep track of ethnic Hungarian students' mother tongue education on the basis of national statistics and conservative estimates. In general, owing to the expansion of minority education after the end of communism, a significant proportion of ethnic Hungarian children started their education in a Hungarian-speaking primary school in the 2010s. This was the case with $80 \%$ of Hungarian children in Romania, Ukraine and Serbia and $75 \%$ in Slovakia. As a result of the expansion, there is an increasing number of Hungarian students in higher education, but the variety of degree programmes in Hungarian does not meet the demands (Papp Z., 2011; Pletl, 2015). Generally, the higher the level of education, the lower the proportion of Hungarians taking part, so they are likely to attain a lower level of education. According to the 2011 census in Romania, which has the largest Hungarian minority, $14.8 \%$ percent of Romanians and only $10.3 \%$ of Hungarians have higher education degrees (Veres, 2013). Statistics are worse in Slovakia. Whereas $10.4 \%$ of the entire population have higher education degrees, only $5.3 \%$ of Hungarians do so. Even in the 2000s there were 1000 settlements with a Hungarian majority where there was no Hungarian primary education available (Törzsök, 2008). Since Ukraine achieved its 
independence, the number of Hungarian education institutions have been on the increase, and so has been the number of Hungarian classes at each level of education. In the Hungarian region of the country $10.4 \%$ of the age group attended Hungarian primary schools in 2001, but only $4 \%$ of university and college students studied at Hungarian institutions (Molnár \& Molnár D., 2005).

Statistics on education in the Hungarian region of Serbia show that the number of Hungarians in higher education is increasing. In 2004 the proportion of Hungarian college students (their training is shorter) was $11.25 \%$ and that of Hungarian university students was 6\% (Szügyi, 2012).

The performance of education institutions and their students can be compared on the basis of the PISA test results. Data from 2003, 2006 and 2009 clearly show that minority students' performance was below majority students'. However, in Serbia and Romania Hungarian students who were educated in their mother tongue performed better than those who were educated in the language of the majority. In contrast, in Slovakia the performance of mother tongue education is declining year by year (Papp Z., 2013). To make matters more complicated, minority students who take part in majority education usually achieve worse at school and come from a more disadvantaged background. The phenomenon is termed "assimilation spiral" by Papp: deprived of the chance to be educated in their mother tongue, the number of poorly performing minority students will grow, which will prevent the improvement of their social status and will even add to their social disadvantage. The process will reverberate as low-status minority parents do not tend to make informed choices about their children's schooling.

\section{Data and Variables}

For our analysis, we used an international student database called Institutional Effects on Student Achievement (IESA), which was created during the winter of 2014-2015 (Pusztai et al., 2016) by the research centre CHERD-Hungary. We analysed data on 1739 Hungarian students from 13 higher education institutions in five different countries of Central Europe, focusing on one region in each country. We compared data on students from Hungarian institutions or faculties of higher education in Romania, Ukraine, Serbia and Slovakia to corresponding data from universities in Eastern Hungary, as the latter were the most similar to the minority institutions in terms of the social composition of the student population. The database represented full-time, both state-funded and tuition-paying students. The sampling frame was established on the basis of the data provided by the institutions. We contacted the student groups when they were taking part in their university/college courses. The randomness of the sample was achieved by the random selection of these groups. 
During our analysis we tried to find out about the social background of students in minority Hungarian higher education and about the composition of the sources of social capital available to them. We attempted to focus our analysis on the diversity of the composition of the student population across the regions. We formulated our hypotheses on the basis of the statistical features of the communities and the findings of our own research, which goes back over a decade (Pusztai, 2007; 2015). We expected that the proportion of students whose parents had a low level of education would be higher in minority institutions than in schools in Hungary because of the expansion of minority education and the academic and residential mobility of the high-status population.

\section{Students' Social Status}

One of the essential research conclusions of the sociology of education is that there is a close correlation between students' academic achievement and careers and the social status of their families (Pusztai, 2015). According to this approach, students' academic success follows as a result of their families' investment into cultural capital. That is to say, children from higher status families have a greater chance of a successful academic career and entering higher education, which reproduces the disadvantage of the not so well-schooled Hungarian minority.

Our empirical findings showed that in the case of minority families both the fathers' and mothers' level of education was lower than in the case of families from Eastern-Hungary, and the proportion of parents with higher education degrees was relatively low (around $20 \%$ ) in each region of the survey. From this it follows that over four fifth of the students of minority higher education institutions will be first-generation intellectuals after graduation. This leads to the conclusion that minority institutions are socially open and support lowstatus students' careers.

Of the regions of the survey, Hungarian students from Ukraine were in the best position with the highest proportion of parents with university degrees (25\% of mothers and $16 \%$ of fathers) and the lowest proportion of parents with only primary education (18\% of mothers and $18 \%$ of fathers). The proportion of parents with the lowest level of education was the highest among Hungarian students in Romania (38\% of fathers and $20 \%$ of mothers), and they were followed by their peers from Slovakia (30\% of mothers and $31 \%$ of fathers) and Serbia (22\% of mothers and $27 \%$ of fathers). It is worthwhile to note that statistics on the level of education of the entire Hungarian minority population are different: Hungarians in Romania have the highest level of education, followed by Serbians, Slovakians and Ukrainians. However, one has to consider that in Ukraine the structural advantage of the parents' age group is due to the fact that in the Ukrainian system some secondary and "halftertiary" qualifications, which have not belonged to higher education anywhere else on the 
basis of their curricula and the duration of the training, count as higher education qualifications. The still lower total education levels of Romanian and Slovakian parents may suggest that mother tongue higher education is socially even more open there, but they may also imply that high status minority people send their children to majority higher education institutions or to Hungary.

The minority groups of the survey also differed in terms of parents' position on the labour market. The firmest position - second only to parents from Eastern Hungary - was held by parents from Slovakia, with over $80 \%$ having a legal income. They were followed by Romanians (more than 70\%), Ukrainians (more than 60\%) and Serbians (more than 50\%). Labour market position depends on the countries' economic performance. What the regions have in common is that mothers' employment figures are below fathers' although their education level is higher. The widest gap is in the data from Serbia.

However, our data also showed that it was not unemployment but being a housewife which does not provide any regular income - that accounted for the women's side of the above statistics. Human capital theories put unfavourable labour market position down to a low level of education. Another possible explanation might lie in the value system of ethnic Hungarian families and their more traditional division of labour. Compared to the economically more developed regions in Hungary and Slovakia, the proportion of housewives was outstandingly high in Ukraine, Serbia and Romania. It is important to note, however, that there is research evidence that mothers who are not employed (full time) outside the home are more efficient in bringing up their children, with a larger input into their children's future (Coleman, 1988).

The students in the regions of the survey have to face considerable difficulties because of the presence of unemployment in their families; the unemployment rate among fathers is especially high in Ukraine and Serbia. It has already caught our attention during our earlier research that the proportion of fathers on disability pension has been permanently very high in Eastern Hungary and - according to our present data - in Slovakia as well. Although there is a connection between access to work providing a decent income and health statistics (Kopp \& Skrabski, 2006), the above figures do not necessarily suggest that the number of people with a reduced capacity of work is much higher in these two regions, but they rather indicate what kind of escape routes from unemployment there are in each system. The differences between the regions depend on the given country's economic situation, the strictness of work capacity requirements and the range of work opportunities in the black economy. It is important to note that these conditions are not only data on families' social background but they may also influence young people's work-related plans and ambitions. 
Regional diversity is further increased by students' perceptions on their economic situation. Our database was suitable for the measurement of the different dimensions - objective, subjective and relative - of economic status. First we analysed students' objective financial status by asking them to mark the durable goods they owned from a list of nine. There were significant differences between the countries. Students from Slovakia appeared to be in the best position (6.56), followed by Serbians (6.06), Hungarians (5.96), Romanians (5.73) and Ukrainians (5.47). However, objective financial status measured in this way is often more indicative of the family's, and not the student's, financial status. The family's house, holiday home or other durable goods might have come from earlier savings, so we also found it necessary to measure students' subjective financial status. Our findings confirmed the advantage of students from Slovakia: over $40 \%$ claimed to have everything they needed and could even afford extra expenses like travelling. 28\% of students from Hungary, 30\% from Romania, 22\% from Serbia and 19\% from Ukraine were of the same opinion.

The differences between the data on the various dimensions of students' financial status lead us to the conclusion that these variables can be presented only in a descriptive way. For the interpretation of our results we also have to find out about students' and their families' consumption habits and value systems. It is rather obvious that in a community where materialistic values have priority, hardly anybody is satisfied with their economic status. The differences in perception are also due to the countries' different economic performance in the present and recent past. When evaluating one's financial status one inadvertently draws comparisons with the past or the status of other groups. It is important to clarify who students look upon as members of their reference group. For that purpose, it is useful to look at the indicator measuring relative financial status in our questionnaire. We asked respondents to mark their financial status on a 1 to 9 scale in relation to that of other families in their country. On the whole, students considered their own status to be slightly above average, but there were considerable differences between regions. At one end of the scale were Hungarians from Slovakia $(6,33)$, who felt somewhat luckier than their environment; at the other end were Hungarians from Serbia $(4,67)$, who thought they had average financial status. The other ethnic Hungarian communities were in between, i.e. above average. On the whole, among indigenous minority students in higher education it was students from Slovakia who - in spite of their parents' low level of education - had the best financial status even when it was measured from a number of different perspectives. This was primarily due to the country's favourable economic situation.

The position of one's place of permanent residence in the hierarchy of settlements is an important indicator of social status. It is so because residence at a small settlement means worse access to education institutions, cultural and employment opportunities. Large sample data from earlier CHERD-H surveys (2003, 2005, 2008, 2010, 2012) showed that a great proportion (almost four fifths) of Hungarian students from Ukraine came from 
villages, whereas the majority of students from Romania came from cities (Pusztai, 2015). The survey area was extended in 2016. As regards Romania, the dominance of students from county seats (69\%). was still present. The proportion of Ukrainian students from low status settlements was still outstandingly high (60\%), and so was the case with Serbian (52\%), and Slovakian (56\%) students. Comparison to institutions from Eastern Hungary reveals that minority higher education institutions are more open to students coming from villages (21\%). This is, of course, a natural consequence of the settlement patterns of the regions and of the fact that a fair number of urban students enter majority higher education in their country or choose institutions in Hungary.

It is a central issue in education research what communities students become involved with and what spaces they frequently appear in during their years of study. The framework of their interaction is of crucial importance. Previous research has shown that there are considerable differences between on-campus and off-campus students: those who live on campus are less likely to drop out, are more satisfied with their institution, are more likely to continue their studies and take a more active part in extracurricular activities (Tinto, 1993; Windchief \& Joseph, 2015; Pusztai, 2015). Under the circumstances of minority existence the frequent opportunity for establishing intergenerational and intragenerational relationships within an institution may give students a clue to the objective and subjective aspects of the minority experience and strengthen their collective identity. Of the range of possible relationships, this study focuses on living on campus i.e. in a dormitory. According to our data the proportion of students living in dormitories is the largest in Ukraine (42\%). This rate is the second highest in Hungary (33\%), followed by Slovakia (27\%), Romania $(23 \%)$ and Serbia (19\%). Given a dominantly rural student population, the number of dormitories available is of great importance. Unfortunately, there is a shortage of dormitory places in Slovakia and Serbia.

Owing to the context-dependent interpretations it is difficult to compare the circumstances of students from regions so distant from one another, yet there appear to be a few conclusions. There are significant differences between students of minority Hungarian institutions of the different countries in terms of parents' level of education and position on the labour market. Minority existence does not necessarily mean a disadvantaged position in every respect. On the whole, students look upon their families' situation as favourable, but there is a significant diversity among the regions. Students from Slovakia have an indisputable advantage in their relative financial status, while students from Serbia and Ukraine have the most disadvantaged position. The majority of students in Ukrainian, Serbian and Slovakian institutions grew up in villages, while there are more students from cities in the other countries. However, the same settlement type may mean various actual environments in the different regions. 


\section{Conclusion}

Our study gave a picture of the social background, education choices, work attitudes and world views of indigenous Hungarian minority students studying in four countries at higher education institutions where the language of instruction is Hungarian. The point of reference was the subsample of students from such a higher education region of Hungary where students' social background is the most comparable to the minority regions. We also compared the groups to one another. We concluded there is no uniformity among the different countries regarding ethnic Hungarian students' family backgrounds. Minority institutions are very open socially: over three-quarters of their students will be firstgeneration intellectuals. However, the proportion of students whose parents only have primary education is higher in Hungary than in Ukraine or Serbia. Parents' position on the labour market is the best in Slovakia and the worst in Serbia, which correlates with these states' economic situation. Students in Slovakia have the best positions in all aspects of financial status. As for the settlement type of students' places of residence, there is a large number of students in Romania who come from an urban environment, whereas the proportion of students coming from villages is high in Ukraine, Serbia and Slovakia.

\section{References}

Agarin, T. \& Cordell, K. (2016). Minority Rights and Minority Protection in Europe. Lanham: Rowman \& Littlefield

Bacskai, Katinka \& Morvai, T. \& Csánó, J. (2015). Development and competition. Teacher training in the hungarian language in Slovakia. In Pusztai, G. \& Engler, Á. \& RevákMarkóczi I. (Eds.), Development of Teacher Calling in Higher Education (pp. 26-36). Budapest-Oradea, Hungary-Romania: Új Mandátum Könyvkiadó-Partium PPS

Coleman, J. S. (1988). Social Capital in the Creation of the Human Capital. American Journal of Sociology, 94, 95-120. doi:

Cordell, K. \& Agarin, T. \& Osipov, A. (2013). Institutional Legacies of Communism: Change and Continuities in Minority Protection. London, England: Routledge

Csata, Zs. (2004). Az iskolázottsági esélyek társadalmi meghatározottsága az erdélyi magyar fiatalok körében. [The social determination of educational opportunities among Hungarian youth in Transylvania] Erdélyi társadalom, 1, 99-132.

Csernyicskó, I. \& Ferenc, V. (2014). Hegemonic, regional, minority and language policy in Subcarpathia: a historical overview and the present-day situation. Nationalities Papers. The Journal of Nationalism and Ethnicity, 42, 399-425. doi: 10.1080/00905992.2013.867933

Csete, Ö. \& Papp, Z. A. \& Setényi, J. (2010). Kárpát-medencei magyar oktatás az ezredfordulón. [Hungarian education in Carpathian Basin on the turn of millennium] In Bitskey, B. (Ed.): Határon túli magyarság a 21. században. [Indogenous Hungarians in 
21 century] (pp. 44-54). Budapest, Hungary: Köztársasági Elnöki Hivatal [Office of the President of Hungarian Republic].

Despagne, C. (2013). Indigenous Education in Mexico: Indigenous Students' Voices. Diaspora, Indigenous, and Minority Education: Studies of Migration, Integration, 7, 114-129. doi: 10.1080/15595692.2013.763789

Gábrity-Molnár, I. \& Takács Z. (2015). Hungarian-language higher education and primary teacher training in Vojvodina. In Pusztai, G. \& Engler, Á. \& Revák-Markóczi I. (Eds.), Development of Teacher Calling in Higher Education (pp. 11-26). Budapest-Oradea, Hungary-Romania: Új Mandátum Könyvkiadó-Partium PPS

Hanák, P. (1983). Magyarország társadalma a századforduló idején. [Hungarian society on the turn of the century] In Hanák, P. (Ed.), Magyarország története, 1890-1908 [History of Hungary, 1890-1908] (pp. 403-515). Budapest, Hungary: Akadémiai Publishing House

Kanu, Y. (2007). Increasing School Success Among Aboriginal Students: Culturally Responsive Curriculum or Macrostructural Variables Affecting Schooling? Diaspora, Indigenous, and Minority Education: Studies of Migration, Integration, 1, 21-41. doi:

Kopp, M. \& Skrabski, Á. (2006). The significance of health psychology approach in transforming societies, European Health Psychologist, 3, 7-9. doi:

Kozma, T. (2003). Minority education in Central Europe. European Education. 35, 35-53. doi: 10.2753/EUE1056-4934350135

Lambrev, V. (2016). Minority rights and minority protection in Europe, by T. Agarin and K. Cordell. Book review. Diaspora, Indigenous, and Minority Education: Studies of Migration, Integration, 10, 255-257. doi: 10.1080/15595692.2016.1205018

Molnár, J. \& Molnár, D. I. (2005). Kárpátalja népessége és magyarsága a népszámlálási és népmozgalmi adatok tükrében. [Transcarpathian population and Hungarians in the light of demographic and census data] Ungvár, Ukraine: Kárpátaljai Polo Print.

Ogbu, J. U. (1982). Cultural discontinuity and schooling. Anthropology and Education Quarterly, 13, 290-307. doi:

Orosz, I. (2015). Hungarian-language teacher education in Ukraine. In Pusztai, G. \& Engler, Á. \& Revák-Markóczi I. (Eds.), Development of Teacher Calling in Higher Education (pp. 36-48). Budapest-Oradea, Hungary-Romania: Új Mandátum Könyvkiadó-Partium PPS

Papp, Z. A. (2011). The Education Issue. In Bárdi, N. \& Fedinec, Cs. \& Szarka, L. (Eds.), Minority Hungarian communities in the twentieth century (pp. 480-492). Boulder, USA: Atlantic Research and Publications.

Papp, Z. A. (2013). Types of Minority Education: Possible Analysis in Pisa. In Ljubov, S. (Ed.), Russia and Central Europe in the new geopolitical realities (pp. 184-197). Moscow, Russian: Russian Academy of Sciences Institute of Europe.

Pasztor, A. (2006). National Minorities with Respect to Education. The Case of Hungarians. Review of Sociology, 12, 17-35. doi: 10.1556/RevSoc.12.2006.2.1

Pletl, R. (2015). The situation and issues of mother-tongue vocational training in a bilingual educational system: the relations between mother tongue - the language of instruction and the language of the state. In Pusztai, G. \& Engler, Á. \& Revák-Markóczi I. (Eds.), 
Development of Teacher Calling in Higher Education (pp. 49-59). Budapest-Oradea, Hungary-Romania: Új Mandátum Könyvkiadó-Partium PPS

Pusztai, G. \& Bocsi, V. \& Ceglédi T. (Eds.) (2016), A felsőoktatás (hozzáadott) értéke. [Value added of higher education] Oradea-Budapest, Romania - Hungary: PPS, Új Mandátum.

Pusztai, G. (2007). The long-term effects of denominational secondary schools. European Journal of Mental Health, 2, 3-24. doi: 10.1556/EJMH.2.2007.1.1

Pusztai, G. (2015). Pathways to success in higher education: Rethinking the Social Capital Theory in the Light of Institutional Diversity. Frankfurt am Main, Germany: Peter Lang Verlag

Szügyi, É. (2012). Iskolaválasztás a Délvidéken [School Choice in Voivodina]. Kisebbségkutatás, 21, 514-535. doi:

Tinto, V. (1993). Leaving college. Rethinking the Causes ad Cures of Student Attrition. Chicago-London, USA-England: The University of Chicago Press.

Törzsök, E. (2008). Jelentés a külhoni magyarság helyzetéröl. [Report on the Situation of Indigenous Hungarians]. Budapest, Hungary: Miniszterelnöki Hivatal [Office of Prime Minister]

Veres, V. (2013). Népszámlálás [Census] 2011. A népességszám, foglalkozásszerkezet és iskolázottság nemzetiség szerinti megoszlása Romániában [The distribution of population size, occupational structure and level of education by ethnicity in Romania]. Erdélyi társadalom, 2, 23-54. doi:

Windchief A. S. \& Darold, J. H. (2015). The Act of Claiming Higher Education as Indigenous Space: American Indian/Alaska Native Examples. Diaspora, Indigenous, and Minority Education: Studies of Migration, Integration, Equity, and Cultural Survival, 9, 267-283. doi: 10.1080/15595692.2015.1048853 